Andreja Žele

Inštitut za slovenski jezik Frana Ramovša ZRC SAZU, Ljubljana

\title{
Slovenski razvoj besedotvornih pomenov pri izglagolskih samostalnikih, posebno pri glagolniku
}

Z obravnavo izglagolskih tvorjenk je predstavljen razvoj besedotvorne teorije pri nas. Opozorjeno je na različne delitvene kriterije tvorjenk do današnjih raziskav, ki temeljijo na vzročno-posledičnem razmerju med skladnjo in besedotvorjem.

The present paper presents the development of Slovene word-formation theory, the various distributional criteria of complex words, and research which is today based on the cause-effect relationship between syntax and word formation. The paper proposes new possibilities for further research in Slovene word-formation theory.

0 Pri pregledu sem izbrala kronološko zaporedje, tako da je neenakomeren razvoj besedotvorja še izraziteje poudarjen. Pri obravnavanih avtorjih tudi ni poenoteno sodobno teoretično stališče obravnave predvsem zaradi želje predstaviti besedotvorno miselnost posameznega jezikoslovca. Graf $\mathrm{z}$ binarnimi nasprotji in kratična poimenovanja sem povzela po A. Vidovič Muhi; ${ }^{1}$ s tem je nazorneje predstavljen obseg besedotvornih pomenov, in kar je pomembnejše, razmerja med njimi.

VIDOVIČ MUHA: ${ }^{1}$

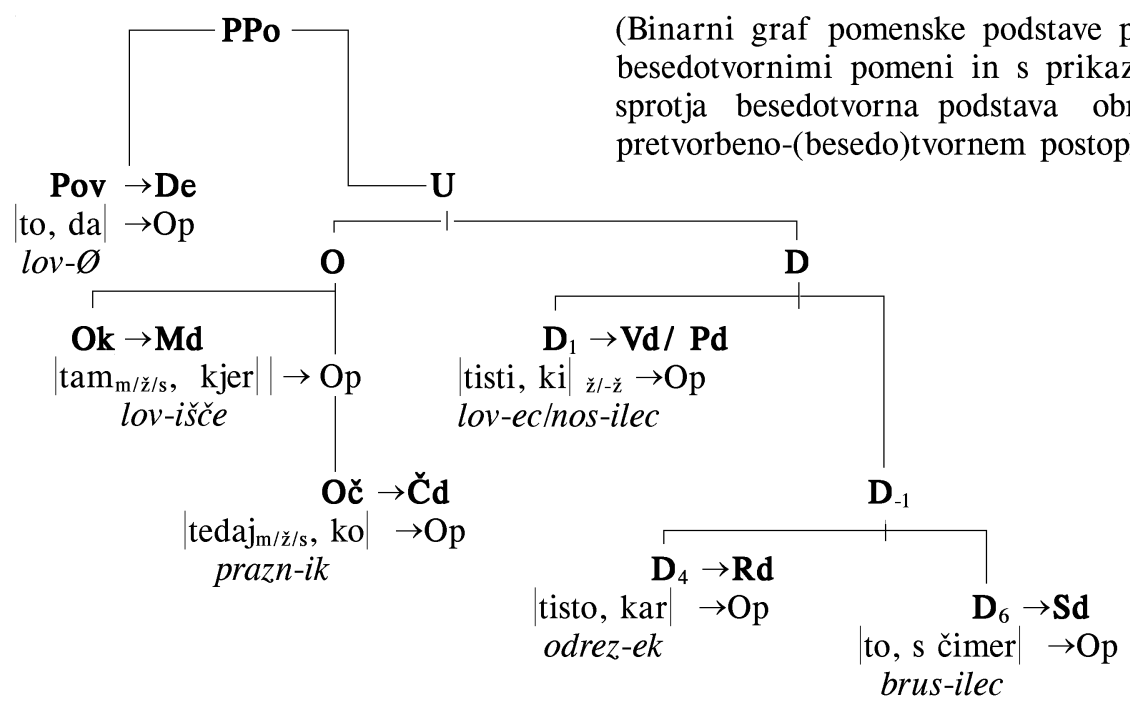

${ }^{1}$ A. Vidovič Muha, SSB ob primerih zloženk, Lj. 1988. Na str. 18 je graf pomenske podstave povedi (PPo) s pretvorbenimi povezavami (primeri izglagolskih tvorjenk). 


\section{Legenda:}
Pov - povedje
Oč - okoliščine časa
De - dejanje
Md - mesto dejanja
$\mathbf{P}$ - pripona
Op - priponsko obrazilo
Čd - čas dejanja
U - udeleženci
Vd - vršilec dejanja
O - okoliščine
Pd - predmet za dejanje
D - delovalnik
Rd - rezultat dejanja
Sd - sredstvo dejanja
Ok - okoliščine kraja

Zgradba grafa kaže hierarhična razmerja med besedotvornimi pomeni (le-ti so pretvorbe določenih sestavin pomenske podstave); izpostavljen je besedotvorni pomen dejanja (De), ki je posamostaljeno povedje in zato tudi osnovna pretvorba.

\section{Uzaveščanje besedotvornih pomenov}

Pri slovničarjih naštevanje priponskih obrazil kaže na priznavanje tvorjenosti besed. Slovničarji so se besedotvornih pomenov zavedali ali jih vsaj slutili, niso pa jih še znali natančno izraziti in opredeliti (tvorjenje besed je opisano kot »delati iz«, »prihajati od«). A. Bohorič »glagolje« (tako poimenuje glagolnik) dela iz nedoločnika - "zlog -ti zamenjamo z -nje«, k temu pa pripomba "ali če ti je ljubše jih lahko delaš iz trpnih deležnikov« (primeri so delanje, pifanje, lublenje, pečenje, pitje). ${ }^{2} \mathrm{Ta}-$ ko je odprl problem, s katerim se jezikoslovci ukvarjajo še danes: je glagolnik tvorjen iz nedoločnika ali iz deležnika na -en. Tvorjenost je izpostavil tudi pri drugih izglagolskih tvorjenkah. Imenoval jih je »Verbalia in povedal, da "prihajajo od « glagolov. Njegovi primeri so delu, lubesan, delavez, kovázh, pifár, pifmu). Za tvorjenke, ki imajo priponsko obrazilo $\mathrm{z}$ besedotvornim pomenom mesta dejanja (Md) ali časa dejanja (Cd) nima primerov.

Opazen je razkorak med jezikovno prakso in med opisom jezika $\mathrm{v}$ Bohoričevi slovnici. ${ }^{3}$ Tako analize Trubarjevih besedil ${ }^{4}$ predstavljajo bogat in raznovrsten repertoar tvorjenk, medtem ko je v Bohoričevi slovnici besedotvorje še skromno, ${ }^{5}$ vendar je skromno predvsem po obsegu besedotvornih vrst (obravnava predvsem izpeljavo), ne pa tudi po pomembnosti ugotovitev.

${ }^{2}$ O tem gl. Šolarjevo oceno Bajčevega Besedotvorja, SR, 4 (1951), 142-148.

${ }^{3}$ A. Bohorič, Arcticae horulae succisivae - Zimske urice proste, Wittenberg 1584, prevod in spremna beseda J. Toporišiča, Maribor 1987, 100-164.

${ }^{4}$ A. Vidovič Muha, Struktura glagolskih tvorjenk v Trubarjevi Cerkovni ordningi, SR, 32 (1984), št. 3, 245-256; Neglagolske tvorjenke v Trubarjevi Cerkovni ordningi, Obdobja 6, Lj. 1986, 349-374, na str. 366: »Razčlenitev tvorjenk v CO dokazuje izoblikovanje besedotvornih vrst in besedotvornih pomenov - strukturna razločevalnost skladenjske podstave je torej enaka današnji / .....\%

5 J. Toporišič, Oblikoslovje v Bohoričevih Zimskih uricah, XX. SSJLK 1984, 189-222, kjer so predstavljene tudi skupine izpeljank v Bohoričevi slovnici $(208,209)$. Na str. 208: »Pri tvorbi nezloženih glagolskih oblik Bohorič ni tako rekoč ničesar prezrl /.../. Med glagolskimi oblikami so tudi glagolniki delanje, pifanje in lubleinje (podč. A. Ž.). Isti avtor je v spremni študiji k prevodu Bohoričevih Zimskih uric prostih (Maribor 1987, 331 str.) na straneh 311-313 obdelal tudi besedotvorje v Bohoričevi slovnici. B. Pogorelec, Dalmatinovo besedilo med skladnjo in retorično figuro in Bohoričeva gramatična norma, 478: »Kratka, a vendar dovolj izčrpna kontrastivna slovnica, ki je 
BOHORIČ: $\quad$ Izglagolski samostalniki

\begin{tabular}{l|l} 
(Glagolje) - Pov - De & \multicolumn{2}{c}{ Udeleženci } \\
-(a)nje/-enje, -tje & Delovalniki Okoliščine \\
(delanje, pifanje, lublenje, & $\mathbf{D}_{1}-\mathbf{V d}$ \\
pezhenje, pitjé) & -vez/-viza, -ázh, \\
Verbalia (izglag. Sam) & -ár \\
na -u, -esan & (delavez, delaviza, \\
(delu, lubesan) & kovázh, pifár) \\
& $\mathbf{D}_{4}-\mathbf{R d}$ \\
& $-\mathrm{mu}$ \\
& $($ pifmu $)$
\end{tabular}

Vsi zgornji izglagolski samostalniki (imenuje jih Verbalia) so $\mathrm{v}$ Bohoričevi slovnici našteti v poglavju De Verbo (Glagol). O tvorbi glagolnika piše $\mathrm{v}$ slovnici na str. 100 in 101.

\section{Oblikoslovnopomensko (analitično) obdobje}

Čas, ki je bil zaznamovan s teorijo Frana Miklošiča - miklošičevsko obdobje. ${ }^{7}$ Vendar tudi predmiklošičevsko obdobje in obdobje pred Vodnikom uvršča $\mathrm{v}$ oblikoslovno obdobje, saj so oblikoslovne lastnosti besed prvotnejše in enostavnejše merilo razvrščanja tvorjenk kot kasnejša pretvorbena merila. Binarni graf pomenske podstave povedi pa je pokazatelj, kateri besedotvorni pomeni so bili upoštevani.

\subsection{Obravnava izglagolskih samostalnikov glede na imenske kategorije}

$\mathrm{V}$ primerjavi z Bohoričevimi spodbudnimi razmišljanji o tvorjenosti besed je to nazadovanje ali vsaj zastranitev, ker je glavno delitveno merilo izglagolskih samostalnikov SPOL in šele znotraj njega so razvrščeni besedotvorni pomeni; tako so besedotvorni pomeni šele drugotno (večkrat čisto naključno) merilo delitve. M. Pohlin, Kraynska grammatika, 1768, 112-117, obravnava besedotvorje pod Von der Verleitung und Zufammenfetzung der Worte (str. 112), priponska obrazila (Op)

poleg traktata o pravopisu obsegala prikaz oblikoslovja po besednih vrstah, vmes nekaj skromnega besedotvorja / .../. A. Vidovič Muha, Struktura glagolskih tvorjenk v Trubarjevi Cerkovni ordningi, SR, 32 (1984), št. 3, 246: »Vsiljuje se vprašanje, kako je besedotvorne možnosti slovenskega jezika predstavila prva slovenska slovnica. Iz konkretne (tudi) besedotvorne razčlenitve (molitev očenaš, 166-178) je razvidno, da Bohorič loči predvsem dve besedotvorni vrsti - izpeljevenje in zlaganje, v katerega uvršča tudi sestavljanje; pri tvorjenki sami loči obrazilni del, zlasti predpono od podstave, npr. po-svečenu (168), iz-idi (169), od-pustimo (172) idr. (podč. avtorica). Zanimivo pa je, da je teoretična izpostavitev besedotvorja skromnejša, vezana pravzaprav le na del izpeljave (nekatere samostalniške in pridevniške tvorjenke).《

${ }^{6}$ A. Vidovič Muha, SSB ob primerih zloženk, 351: »Najpogostejše obrazilo tvorjenk s pomenom dejanja je -nje, ki ima približno 190 primerov; sledi $-\varnothing \mathrm{s} 35$ primeri ter $-a$ z $12, / \ldots /$ « Lahko bi rekli, da graf potrjuje stališče Antona Breznika (Zloženke v slovenščini, Lj. 1944, 329), ki na prvo mesto po pomembnosti uvrsti besedotvorni pomen dejanja (De), takoj za njim pa besedotvorni pomen vršilca dejanja (Vd) ali kot ga on poimenuje "pomen povzročitelja dejanja.«

${ }^{7}$ Poimenovanje povzemam po Adi Vidovič Muhi, SSBPZ 1988; v poglavju Iz zgodovine obravnavanja tvorjenk, zlasti zloženk slovenskega knjižnega jezika, gl. str. 35 . 
deli po spolu. Razvrstitev priponskih obrazil kaže na prevlado izglagolskih samostalnikov z besedotvornima pomenoma dejanja (De) in vršilca dejanja (Vd), kar si na tej stopnji lahko razlagamo kot posledico samodejne težnje jezika, da si izbere besedotvorna pomena, ki sta $\mathrm{z}$ dejanjem najtesneje povezana.

POHLIN:

Izglagolski samostalniki

Delitev Op (priponskih obrazil) glede na SPOL: m.: De: -Ø, -e (krik, tek, pogled, vefsele), Vd: -ar, -azh, -avz, -ik, -ivz, -aj (sidar, kovazh, bravz, sapovednik, brivz, zhuvaj);

ž: De: -Ø, -ava, -a (prepovd, kurjava, navada), Vd: -ariza, -ka, -(n)iza, -avka (pastariza, podpihovavka, porozhniza, poslushavka), Rd -ava (bleščava), Md: -(n)iza (spovdniza);

s: De: $:^{8}$-(t)je/-(-a-/-uva-)nje ${ }^{8}$ (bitje, danje, branje, permiruvanje), Sd: -allu, -ellu, -ilu (nalivallu, gladilu).

M. Pohlin ima v svoji slovnici največ primerov za besedotvorna pomena De in Vd, vendar teh besedotvornih pomenov ni izpostavil. Oba besedotvorna pomena sta namreč vzročno-posledično povezana, zato metonimični prehod med njima ni mogoč, medtem ko je metonimična povezava med glagolniki (De) in izglagolskimi samostalniki z drugimi besedotvornimi pomeni ( $\mathrm{Rd}, \mathrm{Sd}, \mathrm{Md}$, Čd) pogosta. Besedotvornemu pomenu dejanja (De) dodaja še primere za besedotvorni pomen lastnosti (L), npr. uzhenust, dobruta, gerdoba, kar nakazuje Pohlinov jezikovni čut za skupno glagolsko izhodišče teh izglagolskih tvorjenk.

$\mathrm{V}$ okviru premen pa v slovnici na strani 160 našteva glagolske oblike pomagam - pomozh, Shanjem - Shetva, redim - reja, kar vsaj posredno kaže, da se je zavedal tvorjenosti besed.

Globlje kot M. Pohlin je v oblikoslovje zašel O. Gutsman: delitvi po SPOLU dodaja še dopolnilno delitev po SKLANJATVENIH VZORCIH.

O. Gutsman v slovnici Windifche Sprachlehre (Klagenfurt, 1777) omenja glagolnik pri obravnavi sklanjatvenih vzorcev na str. $13 \mathrm{v}$ opombah (Anmerkungen) poglavja II. Abänderung. Nekaj glagolnikov je skupaj z netvorjenimi samostalniki naštetih tudi v poglavju II. AbCchnitt (Fehler in Annehmung fremder Wörter, kjer obravnava vdor nemških besed in njihovo prevlado nad domačimi oz. izvirnimi, str. 141-144). V tem poglavju so glagolniki le prevodi nemških izrazov: »/.../Gemeinde, sdrushba, Hochzeit, shenitva, vdaja /.../« (podč. A. Ž.). Pri teh tvorjenkah (prim. vdaja) ima tudi oblikoslovne napotke. ${ }^{9}$

${ }^{8}$ J. Toporišič, Gutsmanova slovnica, Protestantizem pri Slovencih (Dunajski slavistični almanah, Dunaj 1984), 209-225, str. 220: »Morda je Pohlin slovensko slovnico oškodoval, ko je izmed nedoločnih oblik stare slovnice (prim. WSB 123) izključil gerundij na -di, kar so podajali z nedoločnikom: je zhaI fekati/fekanja /.../« (podč. A. Ž.). Sicer pa imamo natančnejšo predstavitev, ki je obenem tudi ovrednotenje Pohlinovega jezikoslovnega delovanja v Toporišičevi razpravi Pohlinova slovnica (XIX. seminar SJLK, Lj. 1983, 95-128).

${ }^{9}$ O. Gutsman v slovnici Windifche Sprachlehre (1777, Ignaz Ulons Kleinmaner) omenja glagolnik pri obravnavi sklanjatvenih vzorcev na str. 13 v poglavju II. Abänderung v opombah (Anmerkungen). Opozarja, da pri primeru vdaja $\mathrm{v}$ rodilniku množine $j$ prehaja $\mathrm{v} i$ in da to velja za besede, ki se končujejo na -aja, -eja, -oja, -uja ali -va. 


\section{GUTSMAN:}

\section{Izglagolski samostalniki}

(Delitev Op glede na SPOL - sklanjatvene vzorce): I. m. sk1.: De: -Ø, -êh (lov, tepefh), Vd: -(n)ik, -ar, -(i)vez (najemnik, pifar, brivez), Pd: -avz (kazavz), Rd: -Ø, -(i)vez (razhun, brivez);

I. ž. sk1.: De: -ba, -(i)tva, -ja, -a (sdrushba, shenitva, vdaja, osdrava), Sd: -a (pizha), Md: -vniza (delavniza);

II. ž. sk1.: De: -Ø ( (kerb, misel); I. s. sk1.: De: -(a)nje/-enje (barantanje, isvosenje), Rd -ilu (oblazhilu), Sd -ilu (vesilu), Md: -ifhe (tershifhe).

Pod II. žensko sklanjatev je uvrstil še zglede tvorjenk iz pridevnikov s pomenom lastnosti, prim. lenoft, marlivoft. $\mathrm{V}$ isto skupino uvrsti tudi primere, ko se priponska obrazila vežejo na pridevniško podstavo, npr. delavniza, najemnik.

Zgornja preglednica pokaže, da se tvorjenke z besedotvornim pomenom dejanja pojavljajo v vseh osnovnih sklanjatvah (I.m., I.ž., II.ž., I.s.).

Zanimivo je, da so vsi izglagolski samostalniki z besedotvornim pomenom vršilca dejanja v I. moški sklanjatvi (poklici so se omejevali na moške), s čimer že posegamo na področje sociolingvistike.

V slovnici na straneh 142 in 144 je O. Gutsman zajel z zgledi vse besedotvorne pomene razen časa dejanja (Čd), vendar se teh besedotvornih pomenov ni zavedal oziroma jih obravnaval le v okviru sklanjatev.

$\mathrm{Na}$ glagolnike je vsaj posredno, $\mathrm{z}$ vidika pomenske metonimije, ${ }^{10}$ opozoril $\mathbf{J}$. Kopitar v svoji slovnici. Grammatik der Slavifchen Sprache in Krain, Kärnten und Steyermark (Laibach, 1808).

J. Kopitar pri sicer skromni obravnavi izglagolskih samostalnikov ostaja na oblikoslovni ravnini; ${ }^{11}$ v slovnici, 216-300, navaja primere kadilo, krefalo, kropílo, narozhílo, pifmo, raba, drushba), pa še to je le okviru slovensko-nemških primerjav. Po Bohoriču je povzel tvorbo glagolnikov iz trpnih deležnikov - »das vom paffiven participio durch Anhángung der Silbe - je gebildete Substantivum Verbale (délanje, hvalenje, delenje das Abeiten, Loben, Zheilen), « v slovnici, str. 302.

KOPITAR ${ }^{12}$ : $\quad$ Slovensko-nemška protistava: (poudarjen SPOL): homonimija $\mathrm{v}$ nem. primeru leiden

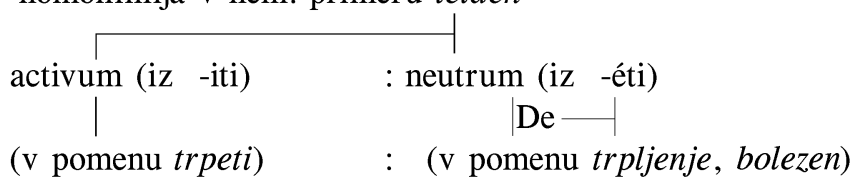

\footnotetext{
${ }^{10}$ Kopitar je to opisal, danes pa ta pojav poimenujemo kot »razlaganje po metonimični poti (J. Toporišič, SS 1976, 129) ali kot »metonimični pomenski razvoj« (A. Vidovič Muha, SSB, Lj. 1988,

${ }^{11} \mathrm{O}$ tem gl. J. Toporišič, Kopitarjeva slovnica - oblikoslovje, SR 28 (1980), 398: »/ .../ tu K/opitar/ le našteva, lahko pa bi bil sestavil že listo ustreznih priponskih obrazil / .../ formalni vidik ima, ko pravi, da grejo sem vse večzložnice na -ast, -ost, -ust (te ima že Gutsman), -azen, -ezen;

${ }^{12}$ A. Vidovič Muha, SSBPZ, Lj. 1988, 35: »J. Kopitar je v svoji slovnici (1808) poleg izrazne podobe jezika in njegove fonološke relevantnosti sicer natančno predstavil oblikoslovje, vendar
} str. 75). / .../.« 
"Nevtrumu leiden « določi besedotvorni pomen dejanja (De) glede na razločevalno skladenjsko vlogo v povedi. Kopitar je v slovnici na straneh 365 in 366 takšne primere tudi razložil: »/.../ na vzhodu je poznano, da vzamejo glagol včasih kot nevtrum « (»wnd bald als Activum vorkommen, wenn ich. z. B fage: der Menfch mufs oft unfchulding leiden - fo gebrauche ich Verbum leiden als ein Neutrum; sage ich aber: Ich mufs grofses Unrecht leiden - fo gebrauche ich leiden als Activum (poud. A. Ž.), /.../ Infinitiv von terpim (ich leide) terpeti /.../ die Neutra, der Konjugation in im haben im Infinitivo -eti, die Activa -iti«).

\subsection{Obravnava izglagolskih samostalnikov glede na glagolske kategorije}

Velik napredek na področju besedotvorja; prvič zasledimo opisno predstavitev besedotvornih pomenov, in tako šele pri V. Vodniku lahko govorimo o začetkih besedotvorne teorije pri nas. ${ }^{13} \mathrm{Za}$ osnovno delitveno merilo sem pri oblikovanju grafov izbrala glagolski vid, ker so ga jezikoslovci tega obdobja pogosto izpostavljali pri tvorbi izglagolskih izpeljank.

VODNIK: ${ }^{14}$

Izglagolski samostalniki (opisna predstavitev besedotvornih pomenov)

Pov - De

Pomenio pofebane dela: -ba, -aria, -ot, -Ø, -a (sodba, sidaria, ropot, tek, $\operatorname{pravda}$ )

\section{Udeleženci}

$\begin{array}{ll}\begin{array}{l}\text { Delovalniki } \\ \text { Vd }\end{array} & \begin{array}{c}\text { Okoliščine } \\ \text { Md }\end{array} \\ \text { Moshake pomenio } & \text { Pomenio hrambe, } \\ \text { k'deblu perdjani } & \text { posode in de- } \\ \text { zlogi: } & \text { lavnize: }\end{array}$

$\begin{array}{ll}\text { Delovalniki } & \text { Okoliščine } \\ \text { m. sp.: -aj, -ak, } & \text {-vniza, } \\ \text {-azh, -an, -ar, -ej, } & \text {-azhniza, } \\ \text {-nik, -ot, -avf, -avt } & \text {-ifhe } \\ \text { (zhuvaj, kovazh, sidar } & \text { (delavniza, } \\ \text { /.../) } & \text { kovazhniza, } \\ & \text { pogorifhe) }\end{array}$

zlasti s stališča pregibanja in tvorjenja (besednih) oblik, besednovrstno pa le posredno, npr. s pomočjo vezavnosti oblikoslovnih kategorij, deloma, npr. pri medmetu, še s pomočjo pomenskih lastnosti / .../. Zlasti v besedotvorju je bila posledica tega normativnost $\mathrm{v}$ veliki meri temelječa na slovensko-nemški protistavi.«

${ }^{13} \mathrm{Na}$ to me je v pogovoru opozorila prof. dr. A. Vidovič Muha.

${ }^{14}$ V. Vodnik, Pifmenost ali Gramatika za Perve Shole, 1811; poglavje Isobrasenje besed s podnaslovom Isobrasenje imen, $148-156$; na str. 150 posredno nakazana tudi pomenska metonimija priponskih obrazil: $» / . . . /$ if he pomeni kraj, ker fe kaj godi, tudi orodje, s'zhim fe kaj dela, kakor: pogorishe, toporishe, kofishe.» 
Pd - pomeni tudi sbor takih Itvari, ktire obdelujemo: -ilo (belilo)

Rd - pomeni glagolovo fturjenje: -aj (lučaj)
Shenlke pomenio:

ž. sp.: -avfla, -otla,

-ajka, -akina, -azhiza,

-anka, -avka, -ejka, -edka,

-ekina, -e्hka, -etla, -ina

(zhuvajka, kuvazhiza ...)

Sd - pomenio orodje: -álo, -elo,

-ilo, -ula, -i「he, -áva

(krefálo, kadilo, ropotula,

kofifhe, kurjava)

Ne loči tvorjenk, pri katerih se priponska obrazila dodajajo pridevniški podstavi: delavniza, kovazhniza. Tvorjenka ropot ima priponsko obrazilo - $\varnothing$, po Vodniku pa priponsko obrazilo -ot; verjetno je to veljalo za vse glagole, ki naj bi bili po takratnih razlagah tvorjeni iz medmetov (v slovnici na str. $150: » / \ldots /$ ot pomeni filneji glaf, kakor: ropot, bobot«). Priponskemu obrazilu vedno določi besedotvorni pomen, vendar se pri navajanju priponskih obrazil opazi, da ima težave $\mathrm{z}$ ločevanjem besedotvornih morfemov $\mathrm{v}$ okviru posameznih tvorjenk. Vrednost in prednost Vodnikovega razmišljanja o besedotvorju je tudi $\mathrm{v}$ tem, da $\mathrm{v}$ nasprotju s svojimi predhodniki zna svoje ugotovitve jasno izraziti, poglavje Isobrasenje beséd, str. 148: »/.../ NaTha befeda perftavla k'fvojmu deblu kakfin slog na konzu, ki ob enim vfe poméni, kar drugi jesiki s'dvema vkup fpopadenma befedama isrekajo, poftavim: nogázh nameft velikanog. Od takih fe bomo sdaj menili.« Sledi podnaslov Isobrasenje imen, pod katerim obravnava tudi izglagolske izpeljanke.

V slovnici na strani 150 je nakazana tudi pomenska metonimija priponskih obrazil: »/.../ -i hhe pomeni kraj, ker fe kaj godi, tudi oródje, s'zhim fe kaj dela, kakor: pogorifhe, /...ltoporifhe, kofifhe.« Poleg besedotvornega pomena stanja, definira ga

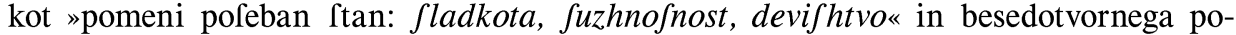
mena lastnosti, ki ga razloži kot "pomeni pofébane lastnosti: fladkoba ter pomenske razlike med njima: » lladkoto miflimo fploh bres vfe fladke ftvari /./, tedaj fladkota je sapopadik mojih milli, lladkobo ima v 'febi pefa, repa, bresova voda«, so $\mathrm{v}$ istem poglavju Vodnikove slovnice predstavljene tudi modifikacijske izpeljanke. ${ }^{15}$

Nadaljevanje Vodnikovega besedotvorja sta Dajnkova in Metelkova slovnica.

P. Dajnko v svoji slovnici Lehrbuch der Windifchen Sprache - ein Verfuch von Peter Dainko (Grätz 1824, 197, 248-249); glagolnik poimenuje Das Zeithauptwort (Verbale).

DAJNKO: Glagolniki (Das Zeithauptwort)

$\begin{array}{ll}\text { deležnik (stanja/trpni) } & \text { izpeljava (Ableitung) } \\ -\mathrm{n}- & -\mathrm{t}- \\ \text { glagolnik na -je } & \text { glagolnik na -je } \\ \text { (delanje, vučenje) } & \text { (odvzetje, početje) }\end{array}$

${ }^{15} \mathrm{~V}$. Vodnik, vir, nav. v op. 13; na str. 151: »/.../ manjfhavni, priasni, lubi, milni perftavki -izh, izhe, izhik (noshizh, ferzhize); manjfhavni shenfki -iza, -izhina (dekliza, gofpo-dizhina); perftavki -on, -azh, -ina pomenio povelizhanje (hlapzhon, bahazh, deklina); grajavni, gerdivni perftavki -uh, -ura, -usa, -avf, -avt (lenuh, babura, babusa, kmetavf, smikavt).« 
Dajnko pove, da je glagolnik tvorjen iz preteklega deležnika in da je tako tvorjeni samostalnik pomensko blizu sedanjiku (197). Primeri pa kažejo, katera priponska obrazila je pri tvorbi glagolnika upošteval: »/.../ delane das Arbeiten, vučene das Lehren, spočetje das Beginnen, odvzetje die Wegnahme.« Na str. 250 še "živlene das Leben, gorene das Brennen, germlene das Donnern, bliskane das Blitzen.« Tudi pri obravnavi spregatev vsakemu glagolu doda glagolnik kot »posebno glagolsko obliko« (str. 199-248).

Pri P. Dajnku prvič zasledimo poimenovanje za besedotvorno vrsto - izpeljava (Ableitung). ${ }^{16}$

Za F. Metelka pa lahko citiram ugotovitev: ${ }^{17}$ „V predmiklošičevski dobi je besedotvorje v Metelkovi slovnici izjemno. Samo za potrditev te misli se ustavimo ob njegovem modernem jezikoslovnem spoznanju o odvisnosti razvrstitve priponskih obrazil od pomena podstave /.../. Metelko sluti povezavo med pomenom podstave in razvrstitvijo priponskih obrazil; /.../.«

\section{METELKO: ${ }^{18}$ Glagolniki (Verbalia)}

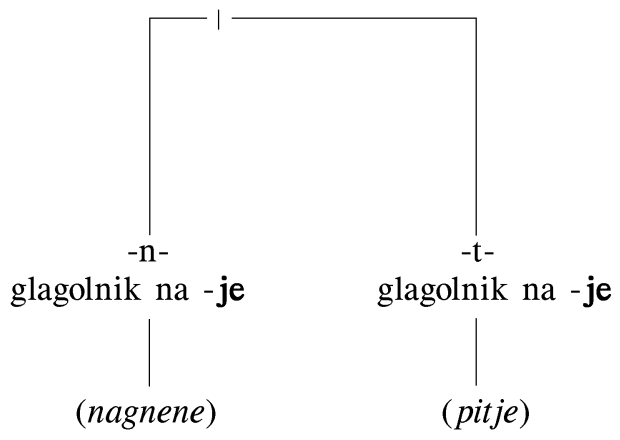

Izbral je šest glagolov $\mathrm{z}$ različnimi glagolskimi priponami in $\mathrm{v}$ zaporedju nedoločnik - deležnik na -n/-t - glagolnik prikazal tvorbeni postopek (npr. pitb

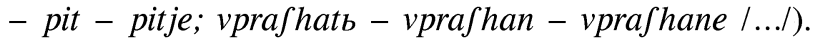

V slovnici pod naslovom Verbalia (142) pripominja: »/.../ vstajéne, die Auferstehung, vstajáne ali vstane sta manj navadni tvorjenki« (podč. A. Ž.).

Potrebno pa je pripomniti, da se Metelko pri podajanju besedotvorja zgledoval po Dobrovskem. ${ }^{19}$

16 P. Dajnko je uporabil natančen izraz za besedotvorno vrsto (249): »Da aber doch alle des Verbals (Zeithauptwortes) fähig find, fo gibt man der Ableitung (podč. A. Ž.) wegen auch diefen früher formel das leidende Mittelwort, als man ihre Verbalien bildet, z. Bedéutung shivlen, goren, germlen, bliskan, Verbalien shivlene das Leben, gorene das Brennen, germlene das Donnern, bliskane das Blitzen« (podč. A. Ž.).

${ }^{17}$ Gl. A. Vidovič Muha, SSBPZ, Lj. 1988, str. 34, 35.

${ }^{18}$ F. Metelko, Lehrgebäude der Slowenifchen Sprache im Königreiche Illyrien und in den benachbarten Provinzen, 1825; v okviru poglavja Bildung des Zeitwortes je tudi naslov Verbalia, str. 142.

${ }^{19}$ Gl. J. Toporišič, Kopitarjeva slovnica - oblikoslovje, SR 28 (1980), 411. 
Metelku sledi A. Murko. Njegovo besedotvorje v Theoretifch-praktifche Slowenifche Sprachlehre (Gräz, 1832) in v Theoretifch-practifche Grammatik der Slowenifchen Sprache (Gräz, 1843) lahko strnemo v shemo:

MURKO:

\section{Glagolniki}

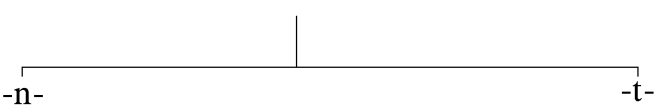

glagolniki na -je

glagolniki na -je

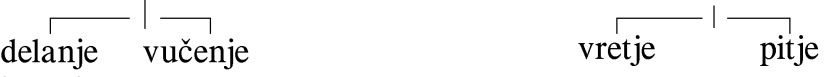

igranje

vprašanje

Izpostavil je »časovne samostalnike« iz nedovršnikov in dovršnikov.

Nakazal je hierarhijo besedotvornih pomenov, ko je dviganje, vsdiganje označil kot dejanje (De), ki izraža trajanje, dvignjenje, vzdignjenje pa kot rezultat dejanja (Rd), ki izraža dokončnost dejanja. stiku.

Želja ustvariti slovensko jezikoslovno terminologijo je zelo izrazita pri F. Lev-

F. Levstik je učitelj normativnosti (v zvezi z njo je izpostavil tudi glagolnik) in vzgojitelj na mišljenjski ravni, saj je s svojimi razlagami posegel v globinsko strukturo jezika.

Glagolnike omenja F. Levstik v svojih Jezikovnih spisih (X. knjiga Levstikovega $Z D, 158)$. Omenja jih kot eno izmed sestavnih lastnosti nedovršnih glagolov: "Nedovršljivi glagoli pa morajo imeti /.../ d) glagolšček (substantivum verbale)." Pod opombo pa še: „Glagolščeke slovanska narečja prav delajo samo iz nedovršljivih glagolov, ker si pri tem vedno le trajanje mislijo« (poud. A. Ž.).

LEVSTIK: $\quad$ Glagolniki - Glágolščeki (Substantivum verbale)

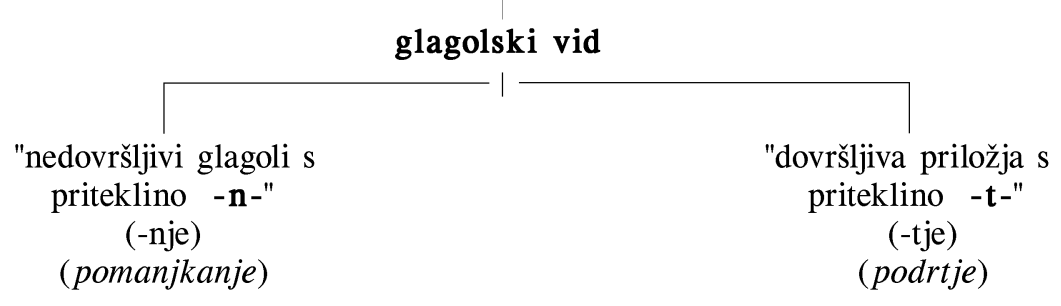

Eden izmed Levstikovih nasvetov je, naj, kjer je to mogoče, namesto nedoločnika vselej naredimo glagolsko ime..$^{20}$

${ }^{20}$ V Napakah slovenskega pisanja, VI. knjiga Levstikovega ZD, 52, pa beremo: "Za = zum z nedoločnikom, n. pr.: "pero za pisati «. To menda vsak ve, da je tuje, ali vendar se bere časi tudi po knjigah morda zato, ker je prišlo jako v navado celo po tistih krajih, koder se najčisteje govori. Slišal sem Dolenjca: »Ta riba ni za jed«; »nema ništa za jelo«. Tukaj moramo tedaj namesto nedoločnika vselej narediti glagolsko ime (podč. A. Ž.). 
V Napakah slovenskega pisanja (1858) je izpostavil tudi problematiko izbire pomenskih sestavin po načelu, da je duh naroda dostopen $z$ analizo jezika. V SSB, na str. 46: »/.../ Pri Levstiku se namreč že srečamo z modernim strukturalističnim ločevanjem predmetnosti, zlasti pa vsebine in poimenovanja (ubeseditve), ali kakor pravi sam, z ločevanjem »misli« od »zaznamovanja« te misli; o tem, kako se bo zaznamovala »misel«, bo odločal »duh jezika«. V bistvu gre torej za spoznanje, da je prevedba določene vsebine (predmetnosti) $\mathrm{v}$ pomen $\mathrm{v}$ obeh jezikih, nemškem in slovenskem, mogoča $\mathrm{z}$ izpostavitvijo različnih lastnosti te vsebine na vsebinski ravni, kar ima za posledico različnost pomenskih sestavin $\mathrm{v}$ obeh jezikih na pomenski ravni $/ . . . / . \lll$

Prva obsežnejša slovenska slovnica je slovnica A. Janežiča, posebej njena druga, predelana izdaja iz leta 1863. koslovja.

V Janežičevi slovnici (1854) se tvorjenje besed obravnava kar v okviru obli-

\section{JANEŽIČ: ${ }^{21} \quad$ Izglagolski samostalniki}

\section{Pov - De}

-Ø, -et, -ev, -ezen/-azen, -nja, -ot, -ilo, -ba, -ej, -ež, -(j)a, -ija, -je (lom, trepet, kletev, bolezen, bojazen, vožnja, ropot, oznanilo, strežba, pomiglej, tepež, reja, razpertija, pitje)

Pd - -(i)lo (zdravilo)

Rd - -lej, -ljej, -ek (vgrizlej, vzdihljej, pridelek)

\section{Udeleženci}

\section{Delovalniki Okoliščine}

Vd

m. sp.: -áč, -arnica, -á, -ar, -ba, -išče -telj, -ir, -nik, -ež borišče) (beráč, strežá, pisar, godba, učitelj, pastir, stvarnik, grabež)

ž. sp.: -ačica, -azen, -ilja

(beračica, bojazen, šivilja)

Sd - -(a)ča, -áj, -ilo, -ivo

(vertača, deržáj, mazilo, gradivo)

Za trepet in ropot navaja priponski obrazili -et in -ot in njun pomen opiše kot »kaže kako precej važno djanje, p. trepet, dersket, hropet « in »kažejo kak glas, ki se večkrat ponavlja, p. ropot, pleskot, šumot «. Iz teh primerov je še nazorneje razvidno, da tvori glagole iz medmetov in od tod potem priponski obrazili -et in -ot.

Druga našteta priponska obrazila (str. 13, naslov Najnavadniše končnice) so pomembna predvsem s stališča pomenske metonimije obrazil, npr.: »/.../ -áj pomenja služečo osebo, orodje ali prostor: čuváj : deržáj : tečáj.«

\footnotetext{
${ }^{21}$ A. Janežič, Slovenska slovnica s kratkim pregledom slovenskega slovstva, 1854; poglavje Zlaganje samostavnih imen, $12-15$, na str. 68 a) glagolno ime /.../. Upoštevane so še izdaje (2. izd. 1863; 5. izd. 1876; 6. izd. 1889; 7. izd. 1894; 8. izd. 1900; vse v Celovcu).
} 
Glagolniki - Glagolna imena (»razodevajo dejanje v samostalnikovi obliki «, SS 1894, str. 235)

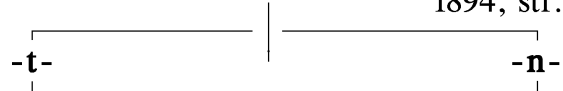

glagolnik na -je

glagolnik na -je

(pitje)

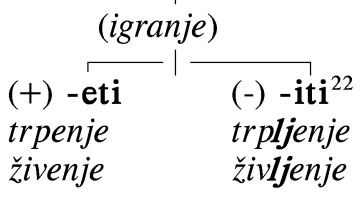

V poglavju Zlaganje samostavnih imen A. Janežič v svoji slovnici navaja še tvorjenke s priponskim obrazilom -Ø (lom, grom), vendar nikjer ne opozori na njihov besedotvorni pomen. Pri tvorjenkah s priponskim obrazilom -Ø ga zanimajo samo samoglasniške premene zveneti - zvon, germeti - grom.

Osrednja avtoriteta oblikoslovnopomenskega obdobja je F. Miklošič. Z njegovim poznavanjem in $\mathrm{z}$ njegovo analizo oblikoslovnopomenskih lastnosti podstavnih $^{23}$ besed se je besedotvorje dokončno osamosvojilo in izstopilo iz okvira zgolj oblikoslovnih obravnav.

MIKLOŠIČ: ${ }^{24} \quad$ Izglagolski samostalniki

\section{Pov - De}

$-\varnothing,-\mathrm{a},-\mathrm{o},-\mathrm{je},-\mathrm{tje},-\mathrm{ija}$, -(a)j, -aj, -(j)a, -ina, -ezen, -ota, -t, -(a)va, -k, -ka, -c, -ica, -(e)ž, -nja, -stvo, -tva/-tev, -èt, -òt, -da, -ba, -ja (uboj, doliv, stava, obedo, veselje, bitje, drtje, golufija, lučaj, tečaj, beža, bolečina, ljubezen, dremota, propast, menjava, vržek, uganka, prdec, omedlevica, grabež, grožnja, rojstvo, vršitvalldobitev, peket, ropot, pravda, pogodba, prodaja)

\begin{tabular}{ll}
\multicolumn{2}{c}{ Udeleženci } \\
$\begin{array}{c}\text { Delovalniki } \\
\text { Vd }\end{array}$ & $\begin{array}{l}\text { Okoliščine } \\
\text { Md }\end{array}$ \\
-nja, -telj, & -arna, \\
-ka, -ica, & -išče \\
-ec, -ač & (pekarna, \\
(ovčarnja, & pogorišče
\end{tabular}
gonitelj, pevka, skočica, jedec, bahač)

$$
\begin{gathered}
\text { Rd } \\
\text {-ek } \\
\text { (zaslužek) } \\
\text { Sd } \\
\text {-ča } \\
\text { (brisača) }
\end{gathered}
$$

\footnotetext{
${ }^{22}$ Janežič na str. 71 utemeljuje: »Tem pravilom, ki se posnemajopo razločku vezivnega e in i, so bili naši predniki zvesteji od nas, ki so govorili in pisali: živenje in terpenje; ker se življenje in terpljenje, kakor sedaj govorimo, ne more izpeljati od živeti in terpeti, ampak je le prisiljeno iz neprave oblike živiti in terpiti« (podč. A. Ž.).

${ }^{23}$ Po Adi Vidovič Muhi, SSB 1988, v poglavju Iz zgodovine obravnavanja tvorjenk, zlasti zloženk slovenskega knjižnega jezika, 33-50, str. 35 .

${ }^{24}$ F. Miklošič, Vergleichende Grammatik der slavischen Sprachen, zweiter Band, Stammbildungslehre (Wien 1875).
} 
Priponska obrazila za vse besedotvorne pomene so "z vidika sodobnega slovenskega knjižnega jezika« predstavljena V razpravi A. Vidovič Muhe (1992, str. 173-191).

Iz druge knjige Miklošičeve Primerjalne slovnice slovanskih jezikov (Stammbildungslehre) iz leta 1875 sem izpisala vsa priponska obrazila $\mathrm{z}$ besedotvornim pomenom dejanja:

- glasovno prazno (funkcijsko) priponsko obrazilo -Ø: uboj, doliv;

- samoglasniški priponski obrazili: -a (obava, stava), -o (obedo);

- soglasniška priponska obrazila: -lo (kadilo, plačilo), -nja (grožnja, iskušnja), -ina (bolečina, opeklina), -ezen (ljubezen), -ota (dremota, škripota), -t (propast), -tva (vršitva, ženitva), -stvo (samo iz Sam in Prid: selstvo, rojstvo), -tev (vezitev, žetev, delitev), -èt, -òt (bek : beket, blisk : blisket, šep : šepet, brb : brbot), - je (zdravje, veselje), -tje (cvrtje, jetje) -nje (bledenje, hrčanje, stanje, bogovanje, pričevanje, zdavanje), -(j)a (beža, kraja), -aj (lučaj, tečaj), -da (pravda), -ba (bramba, ponudba), -ava (menjava, svečava), -ek (vržek, zaslužek), -ka (uganka, povzemka), -ica (dav-ica, omedlevica), -ec (padec, prdec, udarec), -ez (videz), -ež (grabež, bodež, derež, kladež).

Glagolniki

prvotni substantivi

glagolski vid

nedov. glagoli

(-ije: bytije, pbsanije,

šbstije, otbvrbstije)

iz nedov. glagolov dov. glagoli

(-a: izbava - uporaba je manj navadna)

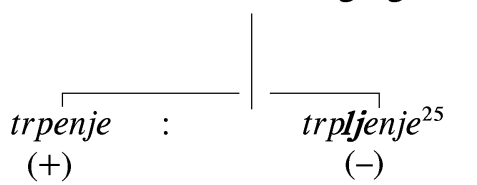

Miklošičeve ugotovitve so ${ }^{26}$ :

a) glagolnik (substantivum verbale) iz nedov. glagolov tudi pri Slovanih označuje abstraktno dejanje in ima abstrakten pomen (str. 877);

b) tvorba iz dovršnika je manj navadna (str. 877); (str. 880);

c) pri pretvorbi glagola $\mathrm{v}$ glagolnik izguba se ne vpliva na glagolski pomen

${ }^{25} \mathrm{~V}$ Vergleichende Grammatik der slavischen Sprachen, 3. del, 170: »/.../ Če v trpnopretekli deležnik vključimo še -lj- je neorgansko, vendar trpljenje, življenje poleg trpenje, živenje in grmenje / .../; poželenje je ustreznejši kot poželjenje«(podč. A. Ž.). $877-880$.

${ }^{26}$ Miklošič v delu Syntax der slavischen Sprachen (Wien 1883) obravnava glagolnik na straneh 
d) važen je vpliv glagolnika na reorganizacijo stavčne zgradbe ${ }^{27}$ (str. 879).

Pri Miklošiču se izraziteje pokaže, da je glagolnik kot posamostaljeno dejanje izločen iz tvorbe debel in potisnjen $\mathrm{v}$ skladnjo, tako postane predvsem skladenjski problem (tč. d).

Po Miklošiču se je zgledoval J. Šuman, to je povedal že v naslovu svoje slovnice Slovenska slovnica po Miklošičevi primerjalni (Lj. 1881).

Šuman je predstavil glagolnik s stališča normativnosti v skladenjski rabi.

ŠUMAN: $\quad$ SKLON (poudarjena skladenjska vloga)

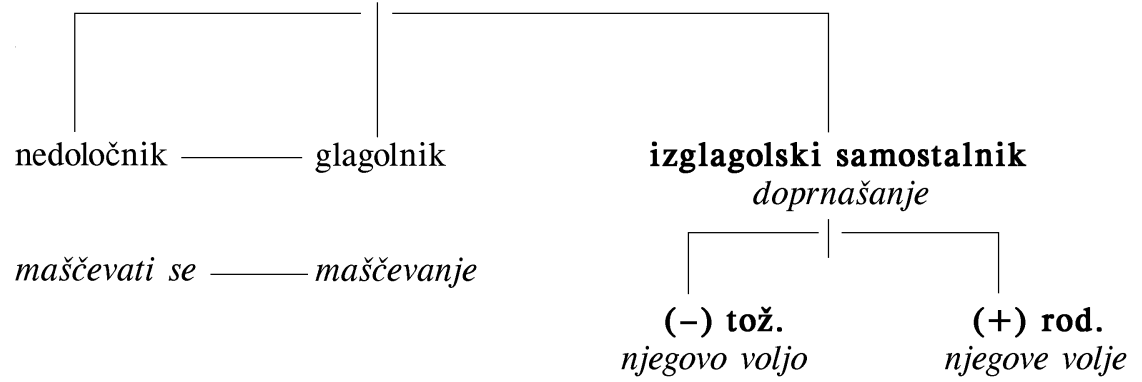

J. Šuman v svoji slovnici na straneh 367 in 368 obravnava glagolnik ali, kot ga sam imenuje, glagolski samostalnik: $» / \ldots /$ glagolnik stoji tam, kder se zahteva določen sklon, nedoločnik pa tam, kder se ima djanje $\mathrm{v}$ obče dopolniti; zato stoji po predlogih le glagolnik: vrzite mreže na lovljenje« (poud. A. Ž.). Za glagolnik J. Suman tudi pravi, da »stavi vsaj v starejših pismih svoj predmet prav po glagolskem $\mathrm{v}$ tožilnik«. Vendar v oklepajih napiše tudi različico v rodilniku: »/.../ streznili bi se vražjih mrež na doprnašanje njegovo voljo (njegove volje)《 (poud. A. Ž.).

Čeprav R. Perušek v svoji razpravi Zloženke $\mathbf{v}$ novej slovenščini (Novo mesto, 1890 ${ }^{28}$ obravnava predvsem zloženke, na straneh 32-36 omenja tudi glagolnik v razmerju z drugimi besedotvornimi pomeni izglagolskih izpeljank. Iz njegovih ugotovitev lahko razberemo željo po logični predstavitvi tvorjenk.

Iz poglavja Imena izvedena iz prefiksovanih glagolov citiram zanimivo ugotovitev, str. 33: »Pri nekterih primerih mogel bi kdo sumnjati, da so besede sestavljene iz gotovega substantiva in prepozicije, npr. v besedi izvoz. Ali ta beseda ni sestavljena iz prepozicije iz in substantiva voz currus, nego je izvedena iz glagolske prefiksovane osnove izvez, od katere imamo glagol izvesti« (poud. A. Ž.).

$S$ tem je Perušek dokazal, da dobro loči morfemizacijske sestave tvorjenk, pa tudi stopnje izpeljave.

\footnotetext{
${ }^{27}$ Kot pretvorbo omenja glagolnik tudi v razpravi Die Verba impersonalia im Slavischen, Wien 1865, 3-48. Na str. 24 pravi, da je v tipični stavčni zgradbi nove slovenščine stvarno ime v tožilniku, včasih pa uporabimo tudi glagolnik (uporablja poimenovanje Verbum substantivum), ki ga ne uporabljamo brez kopule, npr. "gola ljubezen ga je do grešnika, Ravn. 2. 285.« (podč. A. Ž.).

${ }^{28} \mathrm{R}$. Perušek, Zloženke v novej slovenščini (Posebej natisneno iz izvestja novomeške gimnazije za leto $1890,3-42$ ).
} 
PERUŠEK:

Izglagolski samostalniki

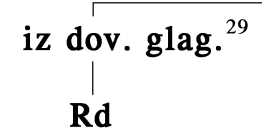

Rd

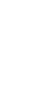

iz nedov. glag.

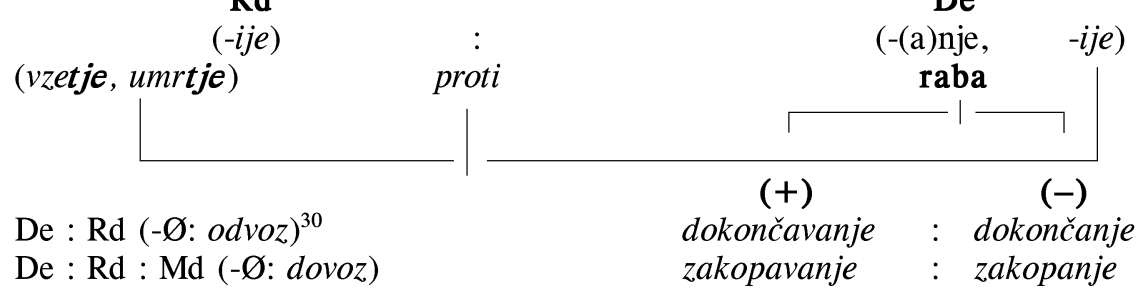

Na str. 34: „Od glagolov izvajajo se (poud. A. Ž.) poleg imen, katera značijo kraj, kjer se kaj godi, ter sredstvo ali orodje, s katerim se kaj godi, posebno še imena, ktera značijo dejanje ali stanje (nomina actionis) in imena, ktera značijo osebo ali stvar, ktera deluje ali se $\mathrm{v}$ kakem stanji nahaja, ali pa na kterej se dejanje in stanje pojavlja (nomina agentis).«Vključuje torej vse besedotvorne pomene razen Čd. Ne ostaja zgolj pri naštevanju primerov za različne besedotvorne pomene, ampak jim skuša določiti tudi pomenske meje (gl. op. 33).

J. Sket $^{31}$ je pri tvorbi glagolnikov poleg glagolskega vida upošteval tudi (ne)prehodnost glagolov, s tem pa je besedotvorje že bliže skladnji.

SKET:

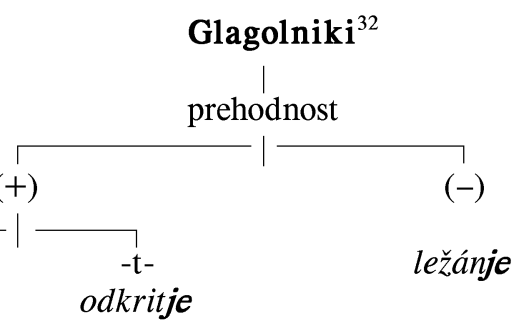

délanje odkritje

${ }^{29} \mathrm{Na}$ str. 32: »/.../ a po pravilu smejo se izvajati iz perfektivnih glagolov substantiva na -ije samo ondu, ako ne pomenjajo dejanja ali stanja, nego efekt ali učinek tega dejanja, ter so postali popolnoma substantivi, v katerih ne čutimo več glagolske radnje, npr. poštenje / .../« (podč. A. Ž.).

30 Tako na str. 35 beremo: »Oblik odvoz ni samo abstrakten pojem, nego postane, kakor v nemščini Zufuhr, ktera beseda je jednako izvedena iz glagolskega korena, okasionalno konkreten. Tako se zovejo namreč ona abstraktna imena, ktera izražajo dejanje v prostoru in času omejeno, $\mathrm{v}$ razliko od onih konkretnih imen, ki znamenujejo kako snovno reč.«

${ }^{31}$ J. Sket, Slovenisches Sprach und Übungsbuch Nebft Chreftomathie und slovenifch-deutfchem und deutfch-slovenifchem Wörter-Verzeichnis (Klagenfurt 1893, na str. 152-154 je 66. Lection - šestinšestdeseta naloga Slovenifche Wortbildungsfilben und deut fche Compofita = Slovenske pritikline in nemške sestavljenke). Janežičeva Slovenska slovnica v predelavi Jakoba Sketa, Celovec 1906. Tretji del slovnice je Besedotvorje; avtor najprej obdela izpeljavo (123-134).

${ }^{32} \mathrm{~V}$ Sketovi slovnici iz 1893. leta (str. 121) beremo, da se glagolniki (imenuje jih Verbalsubstantivi) tvorijo iz trpno-preteklega deležnika s sufiksom -je. Med primeri so: delan - delanje, das Arbaiten; / .../ vpit - vpitje, das Gefchrei. Loči pa Verbalsubstantive, ki so izpeljani iz neprehodnih glagolov: trpljénje, das Leiden; ležánje, das Liegen (podč. A. Ž.). 
Glagolnik obravnava A. Breznik v svoji slovnici Slovenska slovnica za srednje šole (Celovec 1916), na str. 156 pod naslovom Glagolnik.

BREZNIK: $\quad$ Glagolniki (dejanje v samostalniški obliki)

\section{glagolski vid}

$\begin{array}{cc}\text { iz nedov. glag. } & \text { iz dov. glag. } \\ \text { De } & \text { De }\end{array}$

-(e)nje/-(a)nje

(sedenje, vrtenje, bahanje)

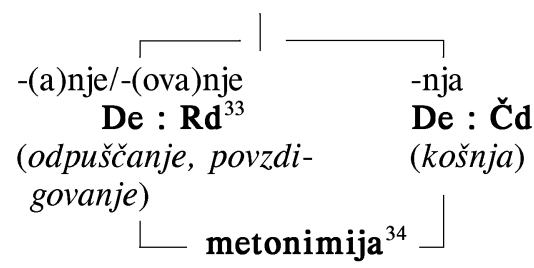

-(i)tev/-(i)tva, -ba, -ek,

-ljaj, - ilo

(dovolitev, naredba, opravek, dogodljaj, opravilo)

Primere z -ek piše v oklepaju, npr. na str. 156: »/.../ opravilo (opravek); dogodljaj (dogodek);/.../«, kar lahko pomeni, da že takrat obrazilo -ek ni bilo povezano samo $\mathrm{z}$ besedotvornim pomenom dejanja.

$\mathrm{Ne} \mathrm{v}$ tako strnjeni obliki piše o glagolniku tudi v razpravi Zloženke v slovenščini (1944), in sicer pod naslovom Glagolske zloženke (str. 327-333). Na primeru zloženke opozori na metonimični pomenski razvoj, ${ }^{34}$ kar pa velja tudi za izglagolske samostalnike.

Pomembno je tudi Breznikovo hierarhično pojmovanje besedotvornih pomenov. To je predstavil s primeri zloženk, str. 326: »V vseh glagolskih zloženkah se da izvesti pomen na dejanje; iz dejanja se je razvil pomen povzročitelja ali kraj ali čas dejanja itd. /.../ drvoseč pomeni najprej dejanje, tj. sekanje drv, po metonimiji (poud. A. Ž.) kraj, kjer se drva sekajo, tj. gozdni del, zavod; v strsl. pomeni drbvosečb povzročitelja dejanja, tj. drvarja /.../.«

Breznikova izpostavitev glagola kot bistvenega stavčnega člena in kot organizacijskega in pomenskega jedra stavka nasprotuje strukturalistični miselnosti o enakovrednosti osebkovo-povedkove zveze pri ubeseditvi prostorsko-časovnega dogodka. ${ }^{35}$

${ }^{33} \mathrm{Na}$ str. 156: $» / . . . /$ Pravega dovršnega glagolnika slovenščina nima, zato si pomaga a) z nedovršnimi glagolniki tudi tam, kjer si mislimo dejanje dovršeno; taki glagolniki so: darovanje, povzdigovanje (pri maši), /.../. Starejših, splošno sprejetih dovršnih glagolnikov, kakor razodetje (razodenje), dopuščenje, priznanje, stvarjenje /.../ itd. se ni mogoče ogibati, ustavljajmo pa se, kolikor se da, novejšim tvorbam!

${ }^{34}$ Breznik v razpravi Zloženke v slovenščini (1944), 327-333, piše: »/ .../ prvotna oblika je bila vodonosb, kar že samo po sebi pomeni neko dejanje (nošenje vode), po metonimiji (ne po metafori, kakor pravi Jagić) pa pomeni tudi povzročitelja dejanja (Wasserträger) in posodo, s katero se vrši dejanje. Končaj - ja je pristopil šele pozneje, da se je razlikovanje pomena bolj poudarilo.«

${ }^{35} \mathrm{~V}$ zvezi s to problematiko me je mentorica opozorila na dve razpravi, ki sta odločujoče vplivali na naš jezikoslovni razvoj: R. F. Mikuš, K sintagmatiki profesorja A. Belića (Lj. 1952), in B. Vodušek, Za preureditev nazora o jeziku (Krog, Lj. 1933, 66-76). 
$1948 .^{36}$ je izšel članek F. Bezlaja Doneski k poznavanju glagolskega aspekta. Omenjam ga, ker opozorja na potrebnost proučevanja glagolskih pripon, ki so del besedotvorja glagola: »/.../ Glagolske pripone, ki služijo v slovanskih jezikih za tvorbo denominativ in deverbativ, glasoslovno še vedno niso dovolj pojasnjene. Ako sprejmemo Meilletovo razlago, da se je prezentna pripona -aie- posplošila po denominativih iz a-jevskih in o-jevskih samostalnikov tipa igra, delo (podč. A. Ž.), bi to $\mathrm{v}$ marsičem osvetlilo nastanek slovanskega glagola /.../.«

Za Miklošičem je najpopolnejši pregled priponskih obrazil napisal A. Bajec. ${ }^{37}$ Popolnejšo predstavo o Bajčevem Besedotvorju I pa dobimo s kritično oceno J. Solarja, ki je izšla samo leto pozneje v SR (let. 4, 1951, 142-148).

BAJEC:

Izglagolski samostalniki

iz dov. glag.

De

-ek, -(i)tev, -(i)lo,

-a, -ba, - $\varnothing,-(a) n j e$

De : $\mathbf{R d}^{39}$

(začudenje, spoznanje, presenečenje)

domenek 'domenjena stvar ali domemba'

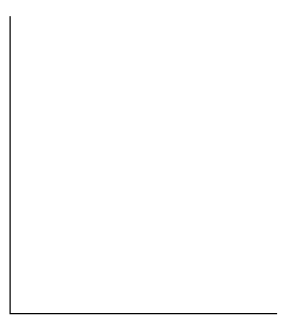

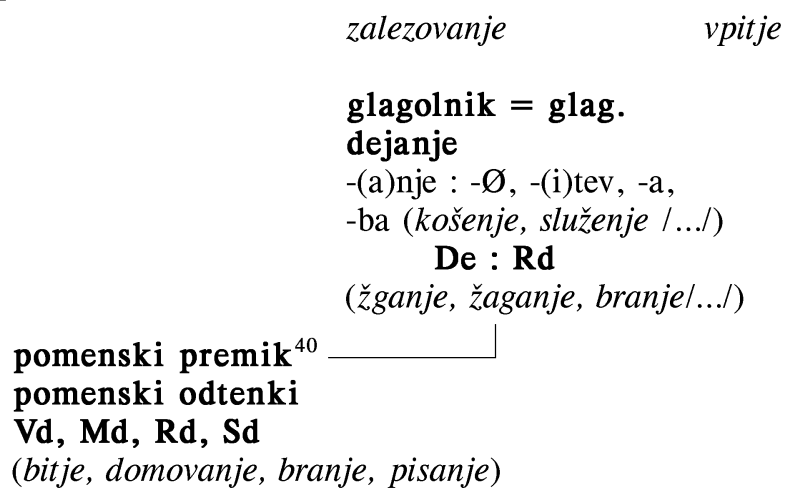

${ }^{36}$ F. Bezlaj, Doneski k poznavanju glagolskega aspekta, SR 1 (1948), 199-220, str. 216.

${ }^{37}$ A. Bajec, Besedotvorje slovenskega jezika I, 1950/52, str. 16, 78, 91, 126-128.

${ }^{38}$ Bajec trdi (vir v op. 51): »/.../ Ker je glagolnik izrazit nomen actionis, so ga prvotno imeli samo nedovršniki /.../.«

${ }^{39} \mathrm{Na}$ str. 16: $» / . . . /$ Belićev sklep velja tudi za slovenščino: jezik ne trpi tvorb za oznako dovršenega glagolskega dejanja, ako le-te ne pomenijo tudi rezultata tega dejanja in imajo zatorej samostalniški pomen. Če pa katero drugo obrazilo pove prav toliko, potem ljudstvo le redko rabi dovršni glagolnik.«

${ }^{40}$ Na str. 29: »/.../ Seveda je pomen utegnil seči prek glagolskega dejanja: naselitev pomeni tudi naselbino / ... /. Vse to so pomenski prehodi, ki jih je doživel tudi glagolnik na -nje, -tje.« 
V Besedotvorju slovenskega jezika $1(126,127,128)$ deli priponska obrazila glede na pomen v 24 pomenskih skupin (naslov na str. 126: Pripone po njih pomenu). Pri naštevanju postavi na začetek pet besedotvornih pomenov v naslednjem vrstnem redu: De, Vd, Rd, Md, Sd; pod točkami 7, 8, 9 sledijo priponska obrazila modifikacijskih izpeljank, med druga obrazila pomeša tudi priponsko obrazilo - $a j$ (pod točko 20 ima lučaj, ki ga opredeli kot »obseg, meja glagolskega dejanja«). Pod točko 22 na str. 128 navaja obrazili -et in -ot z opisom »Imena, ki posnemajo naravne glasove (hehet, hohot).« (podč. A. Ž.).

Slovenska slovnica štirih avtorjev (Bajec - Kolarič - Rupel - Šolar) iz leta 1956 predstavi glagolnik skupaj z glagolom in predvsem s stališča uporabe (str. 237, 238). Na str. 237: »/.../ oranje, brananje, kopánje, vpréganje, razbijanje, čakanje /.../ vpitje, gretje /.../ izgorévanje, grmenje /.../ bitje, žitje. Vsi zgornji glagolniki so narejeni z obrazilom - je na osnovi navideznega trpnega deležnika na $-n$ in $-t$; navideznega zato, ker včasih ustrezni glagol nima tega deležnika; tudi nima nobeden gornjih glagolnikov kakega trpnega pomena, vsi pomenijo tvornost. Vsi so narejeni iz nedovršnikov, prehodnih ali neprehodnih; samo glagolniki iz nedovršnikov res zaznamujejo glagolsko dejanje $\mathrm{v}$ teku. Zato ja ta oblika glagolnika tako razširjena, da nam velja za glagolsko obliko ne za samostojno besedo; v slovnici šteje za pravi glagolnik. Glagolnik delamo navadno le iz nedovršnikov, in sicer $\mathrm{z}$ obrazilom - je na osnovi navideznega trpnega deležnika na $-n,-t$.«

$\mathrm{Z}$ današnjega stališča sta zanimivi ugotovitvi, da »Nekateri nedovršniki izražajo glagolnik s posebnimi besedami na pripone $-t e v,-n j a,-j a,-b a,-l o,-e \check{z}$ ali pa brez pripone « (str. 238) in "Glagolniki so samostalniki po obliki in zvezi. Glagolski osebek in tožilniški predmet sta izražena s prilastkom v rodilniku« (str. 239). V drugi popravljeni izdaji iz leta 1964 pa na str. 213 beremo: »/.../ vrtenje, prerojevanje, /.../ presnavljanje, petje. / .../ besede sodijo med samostalnike, izražajo pa neko dejanje. Narejene so iz glagolskih osnov z obrazilom -je. Imenujemo jih glagolnike. Glagolnik izraža torej dejanje v samostalniški obliki.« Slovnica na področju besedotvorja ne prinaša nič novega, ostaja $\mathrm{v}$ okviru oblikoslovnopomenske analize besed, tej pa ustreza ugotovitev, da je glagolnik dejanje v samostalniški obliki.

\section{Skladenjskopomensko (sintetično) obdobje ${ }^{41}$}

$\mathrm{V}$ sedemdesetih letih se glagolnik obravnava po skladenjskopomenski besedotvorni teoriji, kar s stališča glagolnika pomeni, da so izdelani ustrezni besedotvorni pomeni in skladenjske podstave. Dela in publikacije iz tega obdobja bodo v nalogi primerjalno omenjane in obravnavane pozneje.

${ }^{41}$ Poimenovanji za obdobji pod točkama 2 in 3 povzemam po A. Vidovič Muhi, SSB ob primerih zloženk, Lj. 1988; poglavje Iz zgodovine obravnavanja tvorjenk, zlasti zloženk slovenskega knjižnega jezika, 33-50. 
TOPORIŠIČ $:^{42}$

1. Vd

kdor (človek) bere bralec

kar (žival) poje (ptica) pevka
GPo (govorna podstava); besednozvezna enota na ravni govora
2. Pd
to, $\mathrm{s}$ čimer režemo rezilo
3. De
to, da bere branje
4. $\mathbf{R d}$
to, kar bere
berilo

\author{
5. Md \\ to, kjer seče \\ sečišče
}
6. snov, s katero se kaj dela belež, strelivo
(še »razni posebni pomeni «, ki se dajo uvrstiti med zgornje pomene)

Številke pred besedotvornimi pomeni kažejo, kakšno je zaporedje besedotvornih pomenov pri avtorju (SS 1976, str. 124-130, NSS 1982, str. 337).

Avtor trdi, da besedotvorne pomene razvršča po načelu pomenske strani stavčnih členov, kakor jih ponazarja model stavčne zgradbe: ${ }^{43}$ (1) os., (2) pov., (3) pr., (4) pd.; takšno razvrstitev besedotvornih pomenov sem uporabila za zgornjo grafično predstavitev. Vendar shema stavčne zgradbe vsaki tvorjenki oz. njenemu globinskemu pomenu določi le še površinsko pomensko vlogo, ${ }^{44} \mathrm{ki}$ pa za razumevanje posameznih besedotvornih pomenov tvorjenk ni pomembna.

Kritično razmišljanje o slovenskem besedotvorju omogoča knjiga A. Vidovič Muhe Slovensko skladenjsko besedotvorje ob primerih zloženk, Lj. 1988.

$42 \mathrm{~J}$. Toporišič razlaga svoje pojmovanje šestih pomenskih skupin na straneh $222-223 \mathrm{v}$ razpravi Besedotvorno šolanje, SR 39 (1991), kot pravi, je 6 pomenskih skupin porazdelil po načelu pomenske strani stavčnih členov, kakor jih ponazarja njegov model stavčne zgradbe. A. Vidovič Muha mu v zvezi z izbiro meril za določanje besedotvornih pomenov odgovarja v razpravi Nekaj temeljnih prvin za »besedotvorno šolanje«, SR 39 (1991), 321: »/.../ Končno smo torej dobili kritikovo merilo za število šest $\mathrm{v}$ zvezi $\mathrm{z}$ besedotvornimi pomeni, ki pa se - presenetljivo - v bistvu ne razlikujejo od mojega, le na poved je bilo treba zato pozabiti.«

${ }^{43}$ A. Vidovič Muha, vir, nav. v op. 42, str. 321: »/.../ Kritik je s tem izenačil globinski pomen tvorjenke $\mathrm{z}$ njeno potencialno površinsko pomensko vlogo. / .../ Pri besedotvornih pomenih gre to rej za pretvorbeno zvezo (nemodifikacijske) tvorjenke s propozicijo njene globinske (potencialne) povedi s stavčno zgradbo; nemodifikacijska pripona/priponsko obrazilo je tisti (pretvorjeni) morfem, ki na površinski ravni izraža enega izmed svojih globinskostrukturnih propozicijskih pomenov. Katere skladenjskopomenske vloge privzema že tvorjena (poud. avtorica) beseda, za besedotvorje (poud. avtorica) ne more biti relevantno.«

${ }^{44}$ A. Vidovič Muha, vir, nav. v op. 1; avtorica je za izhodišče števila in vrst besedotvornih pomenov vzela pomensko podstavo tvorjenke; dejanje (De) pa se kot pretvorba povedja v binarnem grafu izloča že v izhodiščni delitvi. 
VIDOVIČ MUHA:

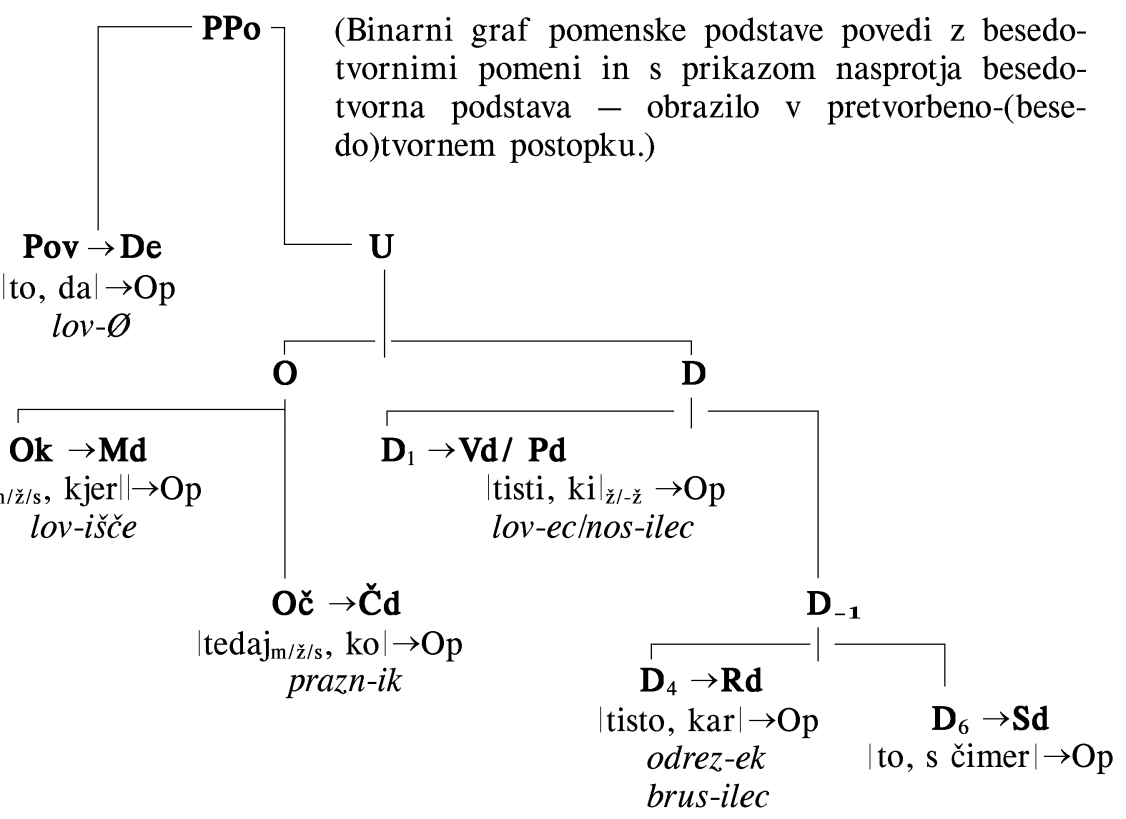

Zgradba grafa kaže hierarhična pomembnostna razmerja med besedotvornimi pomeni (le-ti so pretvorbe določenih sestavin pomenske podstave); posebej izpostavljen je besedotvorni pomen dejanja (De), ki je posamostaljeno povedje.

Novo avtoričino spoznanje za slovenske besedotvorne pomene je, »da je tudi (tvorjena) beseda (poud. avtorica) površinsko strukturirana tako, da z nekaterimi svojimi pretvorbenimi (obrazilnimi) morfemi izraža (globinski) propozicijski pomen; znana (uzaveščena) so torej merila (poud. avtorica), po katerih lahko besedotvorne pomene tako številčno kot vrstno določamo. /.../ njihovo število in vrsta je blokirana s pomensko podstavo povedi ${ }^{45}$

Zgornji graf sem uporabljala za preglednejšo predstavitev razvoja besedotvornih pomenov.

\section{Navedenke}

Bajec, A., 1950/52: Besedotvorje slovenskega jezika I-IV. Ljubljana.

Bezlaj, F., 1948: Doneski k poznavanju glagolskega aspekta. SR 1, 199-220.

Bohorič, A., 1584: Articae horulae succisivae. Wittenberg. Zimske urice proste. Prevedel in spremno besedo napisal J. Toporišič. (Maribor 1987).

${ }^{45}$ A. Vidovič Muha, vir, nav. v op. 42, str. 321. 
Breznik, A., 1916: Slovenska slovnica za srednje šole. Celovec.

- - 1944: Zloženke v slovenščini. Ljubljana: AZU II. 55-76.

- - 1982: Jezikoslovne razprave. Izbral in uredil J. Toporišič. Ljubljana: Slovenska matica. 5-458.

Dajnko, P., 1824: Lehrbuch der Windifchen Sprache. Grätz.

Gutsman, O., 1777: Windifche Sprachlehre. Grätz.

Janežič, A., 1854: Slovenska slovnica s kratkim pregledom slovenskega slovstva. Celovec (še 2. izd. 1863, 5. izd. 1876, 6. izd. 1889, 7. izd. 1894, 8. izd. 1900).

Kopitar, J., 1808: Grammatik der Slavifchen Sprache in Krain, Kärntenn und Steyermark. Ljubljana.

Levstik, F., 1858 a: nav. po izd. 1956. Jezikovni spisi. X. knjiga Levstikovega ZD. Ljubljana: DZS.

- - 1858 b: nav. po izd. 1956. Napake slovenskega pisanja. VI. knjiga ZD. Ljubljana: DZS.

Metelko, F., 1825: Lehrgebäude der Slowenifchen Sprache im Königreiche Illyrien und in den benachbarten Provinzen. Ljubljana.

Miklošič, F., 1865: Die Verba impersonalia im Slavischen. Wien.

- - 1868-1874: Vergleichende Syntax der slavischen Sprachen. Wien. 125-249.

- - 1875: Vergleichende Stammbildungslehre der slavischen Sprachen. Wien

Perušek, R., 1890: Zloženke v novej slovenščini. Novo mesto. 3-42.

Pohlin, M., 1768: Kraynska grammatika. Ljubljana. 112-117.

Prunč, E., 1983: Textologische Grundlagen und lexikologische Untersuchung seiner Sprache. Graz.

Sket, J., 1893: Slovenisches Sprach und Ubungsbuch Nebft Chreftomathie und slovenifch-deutfchem und deutfch-slovenifchem Wörter-Verzeichnis. Celovec. 296 str.

- - 1906: Janežičeva Slovenska slovnica v predelavi Jakoba Sketa, 3. del = Besedotvorje. Celovec. 123-134.

Toporišič, J., 1976: Slovenska slovnica. Raba glagolskih oblik. Maribor: Obzorja. 338-339.

- - 1980: Kopitarjeva slovnica - oblikoslovje. SR XXVIII/4. 395-413.

- - 1981: Norma in predpis v Kopitarjevi slovnici. SR XXIX/2. 123-148.

- - 1983: Pohlinova slovnica. XIX. SSJLK. Ljubljana. 95-128.

- - 1984 a: Oblikoslovje v Bohoričevih Zimskih uricah. XX. SSJLK. 189-222.

- - 1984 b: Gutsmanova slovnica. Dunajski slavistični almanah. Wien. 209-225.

Vidovič Muha, A., 1984 c: Struktura glagolskih tvorjenk v Trubarjevi Cerkovni ordningi. SR XXXII/3. 245-256.

- - 1986 a: Neglagolske tvorjenke v Trubarjevi Cerkovni ordningi (16. stoletje v slovenskem jeziku, književnosti in kulturi). Obdobja 6. Ljubljana. 349-374.

- - 1988: SSB ob primerih zloženk. Ljubljana. 
- - 1992: Besedotvorna tipologija »novoslovenskega« gradiva pri Miklošiču. Miklošičev zbornik. 173-191.

Vodnik, V., 1811: Pifmenoft ali Grammatika sa Perve Shole, Ljubljana.

Prispelo januarja 1996, sprejeto decembra 1996

Received January 1996, accepted December 1996

\section{Slovenski razvoj besedotvornih pomenov pri izglagolskih samostalnikih, posebno pri glagolniku}

Glagolnik $\mathrm{z}$ besedotvornim pomenom dejanja (De) je kot izglagolsko tvorjenko med glagolske oblike uvrščal že A. Bohorič in ga poimenoval glagolje. Zastranitev besedotvorne problematike pomeni obravnava izglagolskih tvorjenk glede na spol pri M. Pohlinu in O. Gutsmanu. Vendar tolikokrat ponovljeni spol kot delitveno merilo tvorjenk dokazuje in opravičuje obstoj skladenjske podstave tvorjenke $\mathrm{z}$ izraženim spolom - tako skladenjska podstava predstavlja vmesno slovnično pretvorbeno stopnjo med tvorjenko in njeno pomensko razlago.

Pravi začetek besedotvorja je pri V. Vodniku, ki je opisno predstavil besedotvorne pomene izglagolskih tvorjenk. Nadaljnji razvoj besedotvorja je opazen pri P. Dajnku in F. Metelku. Slednji se je zgledoval po J. Dobrovskem. Pri P. Dajnku pa prvič zasledimo poimenovanje za besedotvorno vrsto izpeljava - Ableitung.

F. Levstik je obravnaval glagolnik s stališča jezikovne norme in ga poimenoval glagolšček ali tudi glagolsko ime, ki naj bi v stavkih nadomeščalo nedoločnik.

F. Miklošič je besedotvorje postavil kot samostojno problemsko področje. Pri njegovih razčlembah tvorjenk stopa $\mathrm{v}$ ospredje razmerje pomen : oblika. $\mathrm{Z}$ obsežnim številom priponskih obrazil je Miklošič predstavil vse besedotvorne pomene z možnimi metonimičnimi pomenskimi premiki tvorjenk, posredno pa je opozoril na povezavo besedotvorja in skladnje in na njuno medsebojno odvisnost. To pa so že zametki skladenjskega besedotvorja.

$\mathrm{Na}$ tvorbene posebnosti glagolnika in tudi drugih izglagolskih samostalnikov s stališča glagolskega vida in glagolske (ne)prehodnosti so opozorili R. Perušek, A. Breznik in A. Bajec; slednji je priponska obrazila razvrstil v 24 t. i. pomenskih skupin.

Današnje raziskave J. Toporišiča in A. Vidovič Muhe pa temeljijo predvsem na vzročno-posledičnem razmerju med skladnjo in besedotvorjem in odpirajo možnosti za nadaljnje raziskave na področju slovenskega besedotvorja. 


\section{The Slovene Development of Meanings in Deverbal Nouns, with Particular Reference to the Verbal Noun}

The verbal noun with the word-formational meaning of Action (De) as an ordinary substantival derivative from a verb by suffixation was classifed as early as A. Bohorič, who used the term glagolje. A certain stagnation and deviation from progress toward a theory of word-formation is the treatment of substantival derivatives based on gender by M. Pohlin and O. Gutsman. Nevertheless, the fact that gender as a distributional criterion of a complex word is such a recurrent feature also demonstrates the importance of the syntactic base with expressed gender - so the syntactic base represents an intermediate grammatical transformational phase between a complex word and its semantic base.

The true beginning of Slovene word-formation is represented by V. Vodnik with the description of word-formational meanings of substantival derivatives from verbs. Further developments in word-formation are observed in Dajnko's and Metelko's grammars. F. Metelko had taken J. Dobrovský as a model, and P. Dajnko introduced the term Ableitung for ordinary derivation by suffixation.

A normative view of the treatment of the verbal noun is represented by $F$. Levstik with the terms glagolšček or glagolsko ime, which may substitute for the infinitive.

Slovene word-formation was recognized as an independent linguistic field by F. Miklošič. His theory of word-formation revealed the relationship meaning : form. A comprehensive inventory of suffixal formants represents all word-formational meanings, including the possible metonymic meaning shifts of derivatives. Miklošič had also pointed out of the relationship between word-formation and syntax, and thus to him we may ascribe the concept of syntactic word-formation.

The formational peculiarities of verbal nouns and of others substantival derivatives with respect to verbal aspect and (in)transitive verbs are presented by R. Perušek, A. Breznik and A. Bajec. Finally, all suffixal formants are classified in twenty-four groups.

Today the research of J. Toporišič and A. Vidovič Muha are based on the cause-effect relationship between syntax and word-formation and their research opens new possibilities for further research in Slovene word-formation theory. 